\title{
Nanomedicines: current status and future perspectives in aspect of drug delivery and pharmacokinetics
}

\author{
Young Hee Choi ${ }^{1}\left[\right.$ Hyo-Kyung Han ${ }^{1}$
}

Received: 12 October 2017 / Accepted: 8 November 2017 / Published online: 28 November 2017

(c) The Author(s) 2017, corrected publication November 2018

\begin{abstract}
Nanomedicines have evolved into various forms including dendrimers, nanocrystals, emulsions, liposomes, solid lipid nanoparticles, micelles, and polymeric nanoparticles since their first launch in the market. Widely highlighted benefits of nanomedicines over conventional medicines include superior efficacy, safety, physicochemical properties, and pharmacokinetic/pharmacodynamic profiles of pharmaceutical ingredients. Especially, various kinetic characteristics of nanomedicines in body are further influenced by their formulations. This review provides an updated understanding of nanomedicines with respect to delivery and pharmacokinetics. It describes the process and advantages of the nanomedicines approved by FDA and EMA. New FDA and EMA guidelines will also be discussed. Based on the analysis of recent guidelines and approved nanomedicines, key issues in the future development of nanomedicines will be addressed.
\end{abstract}

Keywords Nanomedicines $\cdot$ Pharmacokinetics $\cdot$ Delivery $\cdot$ Guidelines

\section{Introduction}

To date, various nanomedicines have been developed and commercially applied in clinical and non-clinical areas. Nanomedicines have shown essential characteristics such as efficient transport through fine capillary blood vessels and lymphatic endothelium, longer circulation duration and blood concentration, higher binding capacity to biomolecules (e.g. endogenous compounds including proteins), higher accumulation in target tissues, and reduced inflammatory or immune responses and oxidative stress in tissues. These characteristics differ from those of conventional medicines depending on physiochemical properties (e.g.; particle surface, size and chemical composition) of the nano-formulations (De Jong and Borm 2008; Liu et al. 2011; Onoue et al. 2014). Efforts to develop these characteristics of nanomedicines are likely to make them available for treatment of specific diseases which have not been efficiently controlled using conventional medicines, because nanomedicines allow

Young Hee Choi

choiyh@dongguk.edu

1 College of Pharmacy and Integrated Research Institute for Drug Development, Dongguk University-Seoul, 32 Dongguk-lo, Ilsandong-gu, Goyang, Gyonggi-do 10326, Republic of Korea more specific drug targeting and delivery, greater safety and biocompatibility, faster development of new medicines with wide therapeutic ranges, and/or improvement of in vivo pharmacokinetic properties (Onoue et al. 2014). Many nanomedicines have been used for the purpose of increasing efficacy and reducing adverse reactions (e.g., toxicity) by altering efficacy, safety, physicochemical properties, and pharmacokinetic/pharmacodynamic properties of the original drugs (Dawidczyk et al. 2014). In particular, higher oral bioavailability or longer terminal half-life can be expected in case of orally administered nanomedicines, leading to reduction of administration frequency, dose and toxicity (Charlene et al. 2014; Dawidczyk et al. 2014). Regulation of pharmacokinetic characteristics of nanomedicines can results in significant advances in their utilization. Considerations of pharmacokinetic characteristics of nanomedicines and formulability for development purposes, direction and status of their development, and evaluation systems are thought to have important implications for effective development and use of more effective and safe nanomedicines. Therefore, we will present examples of effective go/stop evaluation stages through a review of pharmacokinetic characteristics and delivery of nanomedicines, and the status and processes of nanomedicine evaluation by global regulatory agencies through comparative analysis. 


\section{Delivery and pharmacokinetics of nanomedicines}

Changes in pharmacokinetic characteristics of nanomedicines are due to changes in pharmacokinetic properties of their active pharmaceutical ingredients (API), which include longer stay in the body and greater distribution to target tissues, possibly increasing their efficacy and alleviating adverse reactions (Onoue et al. 2014). Regulation of efficacy and/or adverse reactions of nanomedicines is affected by alteration of pharmacokinetics such as in vivo absorption, distribution, metabolism and excretion in the body.

Physiochemical properties of nanomedicines depend on their composition and formulation, which ultimately affect their efficacy and toxicity (EMA 2015a; TGA 2016). Control of physiochemical properties (e.g. composition or formulation) of nanomedicines and adjustment of the degree of binding between nanomedicines and biomolecules eventually regulate in vivo distribution of nanomedicines (EMA 2015a, b; TGA 2016). For example, it has been reported that the type and amount of binding proteins are significantly reduced when nanomedicines are prepared using PEGylated particles. Further, binding of polysorbate coated particles to ApoE was reported to increase their migration to the brain (EMA 2015a; TGA 2016).

Based on the above concepts connecting and efficacy/ toxicity, Table 1 shows targeted delivery methods that can lead to changes in the pharmacokinetics of nanomedicines in the body. Delivery mechanisms of nanomedicines can be divided into intracellular transport, epileptic transport and other types (Table 1). Intercellular transport is regulated and facilitated by intracellularization, transporter-mediated endocytosis, and permeation enhancement through interactions involving particle size and/or cell surface (Francis et al. 2005; Jain and Jain 2008; Petros and DeSimone 2010; Roger et al. 2010). In general, a smaller particle size of nanomedicines increases intercellular transport, which facilitates cell permeation and affects absorption, distribution, and excretion of nanomedicines. In particular, cell internalization by transporter-mediated endocytosis depends on particle size of nanomedicines. When nanomedicine particles are large, opsonization occurs rapidly and their removal from the blood by endothelial macrophages is accelerated. It has been reported that affinity of cell surface transporters to nanomedicines varies depending on the particle size of nanomedicines, and this could also influence rapid removal of large particles from the blood by macrophages. In addition, nanomedicines containing non-charged polymers, surfactants, or polymer coatings which degrade in in vivo due to their hydrophilicity, interact with cell surface receptors or ligands to increase permeability or promote internalization of nanomedicines (Francis et al. 2005; Jain and Jain 2008; Petros and DeSimone 2010; Roger et al. 2010).
In addition, nanomedicines improve intracellular transport of active pharmaceutical ingredients through binding involving bioadhesive polymers or chelates (Table 1) (Bur et al. 2009; Des Rieux et al. 2006; Devalapally et al. 2007; Francis et al. 2005; Jain and Jain 2008; Mori et al. 2004; Roger et al. 2010). Increased intracellular trafficking of active pharmaceutical ingredients coupled to specific proteins, antibodies, and others in polymers in vivo occurs due to opening of tight junctions and/or increased membrane permeability. In particular, introduction of such a feature in anti-cancer agents can improve the effect of chemotherapy, including targeting brain tumors which are inaccessible to drugs bound by tight junctions, increasing tumor cell targeting, and reducing normal cell targeting. Cytotoxicity against normal cells can be minimized and anti-cancer efficacy achieved using such a nanomedicine strategy. Reduction of nanomedicine elimination in lungs during inhalation leads to increased due to reduced degradation and removal by lung mucosa or macrophages, resulting in increased drug retention time and movement of drug to the target.

Using the enhanced permeability and retention (EPR) effect, it is possible to increase anti-cancer efficacy through increasing tumor permeation and retention time. The EPR effect also makes it possible to selectively deliver nanomedicines to target tissue via conjugation to an antibody, protein, peptide, or polysaccharide, which can be used to modify delivery of nanomedicines to target tissues using receptor/ligand interactions or other physiologically specific target cell interactions, modulating drug efficacy or adverse reactions. Nanomedicines coated with hydrophilic material have improved stability, and their opsonization or accumulation in mucus is prevented. By inhibiting macrophage-induced or mucosal instability, nanomedicines can be retained in vivo, e.g., in lung tissue for prolonged periods of time through particle size, control and avoiding removal by mucus ciliates, which could lead to degradation or macroscopic effects in lung mucosa (Bur et al. 2009). Therefore, a variety of formulations have been developed to use delivery mechanisms which can control pharmacokinetics and pharmacodynamics of nanomedicines.

\section{Classification and pharmacokinetic properties of nanomedicines}

Nanomedicines exhibit a range of in vivo kinetic characteristics depending on their formulations. In this context, disadvantages and advantages of each type of formulation commonly used in nanomedicines (Devalapally et al. 2007) are summarized, and pharmacokinetic properties of various nanomedicines formulations are shown in Tables 2 and 3 . 


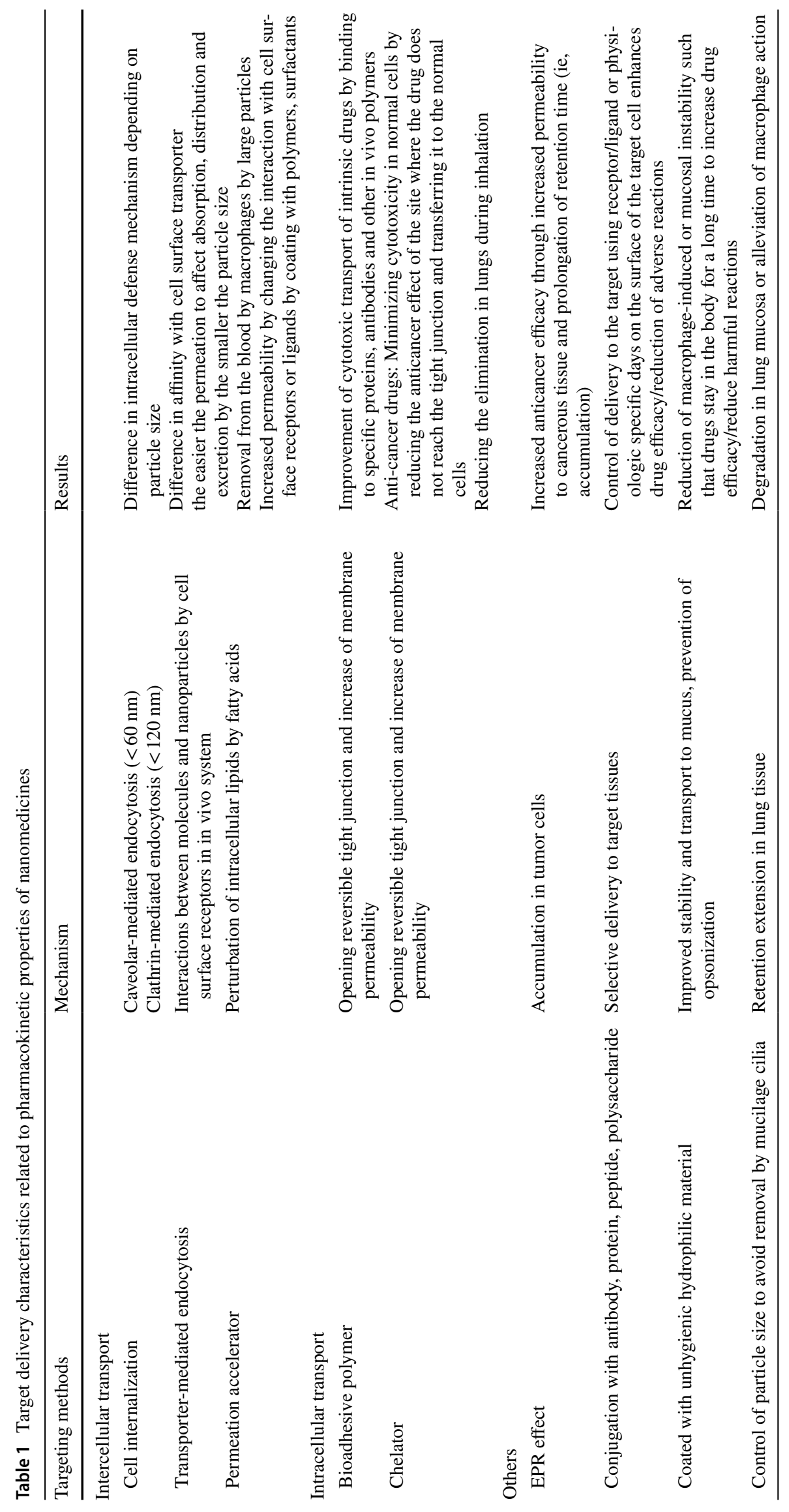


Table 2 Classification of nanomedicines considering pharmacokinetic properties

\begin{tabular}{|c|c|c|c|c|}
\hline \multirow[t]{2}{*}{ Formulations } & & \multicolumn{2}{|l|}{ Pharmacokinetic properties } & \multirow[t]{2}{*}{ Others } \\
\hline & & Advantages & Disadvantages & \\
\hline Dendrimers & $\begin{array}{l}\text { Polysine } \\
\text { Poly(amidoamine) } \\
\text { PEGylated polylysine } \\
\text { Lactoferrin-conjugated }\end{array}$ & $\begin{array}{l}\text { High permeability } \\
\text { Release control } \\
\text { Drug-selective delivery } \\
\text { Improved solubility }\end{array}$ & $\begin{array}{l}\text { Limit of administration } \\
\text { routes }\end{array}$ & $\begin{array}{l}\text { Low immunogenicity } \\
\text { Blood toxicity }\end{array}$ \\
\hline Engineered nanoparticles & $\begin{array}{l}\text { Nanocrystal } \\
\text { SoluMatrix fine particle } \\
\text { Nanosized amorphous }\end{array}$ & $\begin{array}{l}\text { Improved systemic expo- } \\
\text { sure } \\
\text { Increased retention time in } \\
\text { mucus } \\
\text { Various routes of adminis- } \\
\text { tration }\end{array}$ & $\begin{array}{l}\text { Insufficient persistent } \\
\text { emission }\end{array}$ & $\begin{array}{l}\text { Gastric mucosal irritation } \\
\text { relief of NSAIDs } \\
\text { Toxicity by higher Cmax }\end{array}$ \\
\hline Lipid nanosystems & $\begin{array}{l}\text { Emulsion } \\
\text { Liposome } \\
\text { Solid lipid nanoparticle } \\
\text { Lectin-modified solid lipid }\end{array}$ & $\begin{array}{l}\text { Degradation or metabolism } \\
\text { of formulated materials } \\
\text { Improved systemic expo- } \\
\text { sure } \\
\text { Drug-selective delivery } \\
\text { Accumulation in tumor } \\
\text { cells }\end{array}$ & $\begin{array}{l}\text { Quick removal by RES } \\
\text { uptake } \\
\text { Limit of administration } \\
\text { routes }\end{array}$ & $\begin{array}{l}\text { Low toxicity and antigenicity } \\
\text { Cytotoxicity due to surfactant }\end{array}$ \\
\hline Micelles & & $\begin{array}{l}\text { High permeability } \\
\text { Improved solubility } \\
\text { Improved systemic expo- } \\
\text { sure }\end{array}$ & $\begin{array}{l}\text { Insufficient persistent } \\
\text { emission }\end{array}$ & $\begin{array}{l}\text { Low immunogenicity } \\
\text { Cytotoxicity due to surfactant }\end{array}$ \\
\hline Polymeric nanoparticles & $\begin{array}{l}\text { Ethyl cellulose/casein } \\
\text { PLGA alginate, PLGA } \\
\text { PLA-PEG } \\
\text { Hydrogel } \\
\text { Albumin } \\
\text { Chitosan analog }\end{array}$ & $\begin{array}{l}\text { Stable drug release in } \\
\text { in vivo } \\
\text { Increased retention time } \\
\text { of drug }\end{array}$ & $\begin{array}{l}\text { Required initial burst } \\
\text { protection } \\
\text { Limit of administration } \\
\text { routes }\end{array}$ & $\begin{array}{l}\text { Low immunogenicity } \\
\text { Required removal of non- } \\
\text { degradable polymer }\end{array}$ \\
\hline
\end{tabular}

\section{Dendrimers}

Dendrimers are characterized by the presence of polysine, poly(amidoamine), PEGylated polylysine, or lactoferrinconjugated formulations, with high membrane permeability, controlled release ability, selective delivery of active pharmaceutical ingredients, and solubility improvement. There have been reports of limitations in route of administration and immunogenicity, and blood toxicity cases have also been reported (Devalapally et al. 2007; Kawabata et al. 2011; Liu and Fréchet 1999; Mora-Huertas et al. 2010). Applications of dendrimer technology to active pharmaceutical ingredients are exemplified in several reports (Asthana et al. 2005; Barenholz 2012; Chaturvedi et al. 2013; Fanciullino et al. 2013; Feldman et al. 2012; Fetterly and Straubinger 2003; Hanafy et al. 2007; Hrkach et al. 2012; Jia et al. 2003; Jinno et al. 2006; Kaminskas et al. 2011, 2012; Kato et al. 2012; Kawabata et al. 2010; Kurmi et al. 2011; Larsen et al. 2013; Manvelian et al. 2012a, b; Manjunath and Venkateswarlu 2005; Matsumura et al. 2004; Morgen et al. 2012; Onoue et al. 2010a, b, 2011a, b, 2012a, b, 2013a, b; Pandey et al. 2005; Pathak and Nagarsenker 2009; Piao et al. 2008; Pepic' et al. 2004; Prajapati et al. 2009; Reddy and Murthy 2004; Reddy et al. 2004; Sharma et al. 2004; Strickley
2004; Sylvestre et al. 2011; Teshima et al. 2006; Thomas et al. 2012, 2013; Tomii 2002; Watanabe et al. 2006; Wu and Benet 2005; Xia et al. 2010; Zhang et al. 2006, 2008, 2013). Polylysine dendrimer with doxorubicin, an intravenously administered anti-cancer nanomedicine, results in increased systemic exposure and tumor cell of doxorubicin. Poly(amidoamine) dendrimer with flurbiprofen is an intravenously injectable solution with increased distribution to the site of inflammation and increased in vivo retention time. PEGylated polylysine dendrimer with methotrexate or lactoferrin-conjugated dendrimer with methotrexate are intravenous formulations with prolonged systemic exposure and increased lung accumulation, respectively. Poly(amidoamine) dendrimer with piroxicam with is a formulation with increased systemic exposure.

\section{Engineered nanoparticle}

Engineered nanoparticles comprise nanocrystals, solumatrix fine particles, or nanosized amorphous particles, which can improve systemic exposure and decrease retention in the mucosal layer. They can be administered via various routes, but result in insufficient sustained release. Examples of engineered nanoparticle application include reducing gastric 
Table 3 Specific pharmacokinetic characteristics of drugs based on the classification of nanomedicines

\begin{tabular}{|c|c|c|c|c|c|}
\hline Formulations & & API & Techniques & $\begin{array}{l}\text { Admin- } \\
\text { istration } \\
\text { routes }\end{array}$ & PK properties \\
\hline \multirow{5}{*}{\multicolumn{2}{|c|}{ Dendrimer }} & Doxorubicin & Polylysine dendrimer & IV & $\begin{array}{l}\text { Increase of systemic exposure, } \\
\text { accumulation in tumor cells }\end{array}$ \\
\hline & & Flurbiprofen & Poly(amidoamine) dendrimer & IV & $\begin{array}{l}\text { Increase of distribution and reten- } \\
\text { tions in inflammatory sites }\end{array}$ \\
\hline & & Methotrexate & PEGylated polylysine dendrimer & IV & Prolongation of systemic exposure \\
\hline & & & $\begin{array}{l}\text { Lactoferrin-conjugated den- } \\
\text { drimer }\end{array}$ & IV & Accumulation in lungs \\
\hline & & Piroxicam & Poly(amidoamine) dendrimer & IV & Prolongation of systemic exposure \\
\hline \multirow{13}{*}{\multicolumn{2}{|c|}{ Engineered NPs }} & Carbendazim & Nanocrystals & $\mathrm{PO}$ & Increase of oral $\mathrm{F}$ \\
\hline & & Cilostazol & Nanocrystals & $\mathrm{PO}$ & Increase of oral $\mathrm{F}$ \\
\hline & & Curcumin & Nanocrystals & $\mathrm{PO}$ & Increase of oral $\mathrm{F}$ \\
\hline & & Danazol & Nanocrystals & $\mathrm{PO}$ & Increase of oral $\mathrm{F}$ \\
\hline & & Diclofenac & SoluMatrix ${ }^{\mathrm{TM}}$ fine particle & $\mathrm{PO}$ & Rapid absorption, pain relief \\
\hline & & Fenofibrate & Nanocrystals & $\mathrm{PO}$ & Increase of oral F \\
\hline & & Indomethacin & SoluMatrix fine particle & $\mathrm{PO}$ & Rapid absorption \\
\hline & & Megestrol acetate & Nanocrystals & $\mathrm{PO}$ & Increase of oral $\mathrm{F}$ \\
\hline & & Nitrendipine & Nanocrystals & $\mathrm{PO}$ & Increase of oral $\mathrm{F}$ \\
\hline & & Nobiletin & Nanosized amorphous particles & $\mathrm{PO}$ & $\begin{array}{l}\text { Increase of oral } \mathrm{F} \text {, liver protective } \\
\text { effect }\end{array}$ \\
\hline & & Tranilast & Nanocrystals & $\mathrm{PO}$ & $\begin{array}{l}\text { Increase of oral F, rapid absorp- } \\
\text { tion }\end{array}$ \\
\hline & & & $\begin{array}{l}\text { Inhalable nanocrystalline } \\
\text { powders }\end{array}$ & Lungs & $\begin{array}{l}\text { Increase of anti-inflammatory } \\
\text { effect in lungs }\end{array}$ \\
\hline & & Paclitaxel & Albumin nanoparticles & IV & Tumor targeting \\
\hline \multirow[t]{18}{*}{ Lipid } & \multirow[t]{6}{*}{ Emulsion } & Cinnarizine & Self-emulsifying drug delivery & $\mathrm{PO}$ & Increase of oral $\mathrm{F}$ \\
\hline & & Coenzyme Q10 & Solid self-emulsifying delivery & $\mathrm{PO}$ & Increase of oral F \\
\hline & & Cyclosporin A & Self-emulsifying drug delivery & $\mathrm{PO}$ & Increase of oral $\mathrm{F}$ \\
\hline & & & Inhalable dry emulsions & Lungs & $\begin{array}{l}\text { Increase of anti-inflammatory } \\
\text { effect in lungs }\end{array}$ \\
\hline & & Halofantrine & Self-emulsifying drug delivery & $\mathrm{PO}$ & Increase of oral $\mathrm{F}$ \\
\hline & & Simvastatin & Self-emulsifying drug delivery & $\mathrm{PO}$ & Increase of oral F \\
\hline & \multirow[t]{7}{*}{ Liposomes } & Amikacin & Liposome (Phospholipid/Chol) & IV & Increase of half-life \\
\hline & & Amphotericin B & Liposome (PC/Chol/DSPG) & IV & $\begin{array}{l}\text { Increase of systemic exposure, } \\
\text { decrease of RES uptake }\end{array}$ \\
\hline & & Cytarabine/daunorubicin & Liposome (DSPC/DSPG/Chol) & IV & CL reduction \\
\hline & & Doxorubicin & Liposome, PEGylated liposome & IV & $\begin{array}{l}\text { Increase of distribution in tumor } \\
\text { cells }\end{array}$ \\
\hline & & O-palmitoyl tilisolol & Liposome (PC/Chol) & IV & Increase of distribution \\
\hline & & Paclitaxel & Liposome (PC/PG) & IV & Prolongation of systemic exposure \\
\hline & & Prednisolone & $\begin{array}{l}\text { Liposome (PC/Chol/10\% DSPE- } \\
\text { PEG2000) }\end{array}$ & IV & $\begin{array}{l}\text { Prolongation and increase of } \\
\text { systemic exposure }\end{array}$ \\
\hline & \multirow[t]{5}{*}{ Solid lipid NPs } & Azidothymidine & Solid lipid NPs & IV & $\begin{array}{l}\text { Increase of permeability and reten- } \\
\text { tion time in brain }\end{array}$ \\
\hline & & Clozapine & Solid lipid NPs & IV & $\begin{array}{l}\text { Increase of systemic exposure, CL } \\
\text { reduction }\end{array}$ \\
\hline & & Diclofenac $\mathrm{Na}$ & Solid-in-oil NPs & Skin & $\begin{array}{l}\text { Increase of percutaneous absorp- } \\
\text { tion }\end{array}$ \\
\hline & & Insulin & Lectin-modified solid lipid NPs & $\mathrm{PO}$ & Increase of oral $\mathrm{F}$ \\
\hline & & Lidocaine & Solid lipid nanoparticles & Skin & Regulation of skin permeability \\
\hline
\end{tabular}


Table 3 (continued)

\begin{tabular}{|c|c|c|c|c|}
\hline Formulations & API & Techniques & $\begin{array}{l}\text { Admin- } \\
\text { istration } \\
\text { routes }\end{array}$ & PK properties \\
\hline \multirow[t]{5}{*}{ Micelles } & Camptothecin & Block copolymeric micelles & IV & Increase of systemic exposure \\
\hline & Doxorubicin & Block copolymeric micelles & IV & $\begin{array}{l}\text { Increase of systemic exposure, } \mathrm{CL} \\
\text { reduction }\end{array}$ \\
\hline & Paclitaxel & Block copolymeric micelles & IV & $\begin{array}{l}\text { Increase of systemic exposure, } \mathrm{CL} \\
\text { reduction }\end{array}$ \\
\hline & Pilocarpine & Block copolymeric micelles & Eyes & Increase of efficacy \\
\hline & Tranilast & Self-micellizing solid dispersion & $\mathrm{PO}$ & Increase of oral $\mathrm{F}$ \\
\hline \multirow[t]{10}{*}{ Polymeric NPs } & Celecoxib & Ethyl cellulose/casein NPs & $\mathrm{PO}$ & Increase of oral $\mathrm{F}$ \\
\hline & Clotrimazole/econazole & PLGA and alginate NPs & $\mathrm{PO}$ & Increase of oral $\mathrm{F}$ \\
\hline & Docetaxel & PLA-PEG NPs & IV & $\begin{array}{l}\text { Increase of half-life and anti- } \\
\text { cancer effect }\end{array}$ \\
\hline & Doxorubicin & PLGA NPs & IV, IP & $\begin{array}{l}\text { Increase of half-life, decrease of } \\
\text { distribution in heart }\end{array}$ \\
\hline & Glucagon & PLGA NPs & Lungs & $\begin{array}{l}\text { Increase of half-life, increase of } \\
\text { oral } F\end{array}$ \\
\hline & Glucagon & PLGA NPs & Lungs & Increase of oral $\mathrm{F}$ and half-life \\
\hline & Insulin & Hydrogel NPs & $\mathrm{PO}$ & Increase of oral $\mathrm{F}$ \\
\hline & Rifampicin & PLGA NPs & $\mathrm{PO}$ & Increase of oral $\mathrm{F}$ \\
\hline & siRNA & Chitosan analog NPs & $\mathrm{PO}$ & $\begin{array}{l}\text { Increase of systemic exposure, } \\
\text { gene silencing }\end{array}$ \\
\hline & VIP derivative & PLGA NPs & Lungs & Anti-inflammatory effect \\
\hline
\end{tabular}

mucosal irritation due to NSAID nanomedicines, reducing other kinds of toxicity due to high Cmax compared to the original drug (Devalapally et al. 2007; Kawabata et al. 2011; Liu and Fréchet 1999; Mora-Huertas et al. 2010).

Carbendazim, cilostazol, curcumin, danazol, fenofibrate, megestrol acetate, nitrendipine, and tranilast are administered orally by increasing oral bioavailability (F) using nanocrystal formulations. Diclofenac and indomethacin formulations, using SoluMatrix ${ }^{\mathrm{TM}}$ fine particle technology, are oral formulations with improved absorption rates and pain relief. Nanosized amorphous particles of Nobilet show reduced hepatotoxicity (i.e., protection of liver function) with oral F. Inhalable nanocrystalline powder of Tranilast is a formulation administered directly to lungs and with improved anti-inflammatory effect. Albumin nanoparticles of paclitaxel improves targeting variability by increasing delivery to cancer cells when intravenously administered (Asthana et al. 2005; Barenholz 2012; Chaturvedi et al. 2013; Fanciullino et al. 2013; Feldman et al. 2012; Fetterly and Straubinger 2003; Hanafy et al. 2007; Hrkach et al. 2012; Jia et al. 2003; Jinno et al. 2006; Kaminskas et al. 2011, 2012; Kato et al. 2012; Kawabata et al. 2010; Kurmi et al. 2011; Larsen et al. 2013; Manvelian et al. 2012a, b; Manjunath and Venkateswarlu 2005; Matsumura et al. 2004; Morgen et al. 2012; Onoue et al. 2010a, b, 2011a, b, 2012a, b, 2013a, b; Pandey et al. 2005; Pathak and Nagarsenker 2009; Piao et al. 2008; Pepic' et al. 2004; Prajapati et al.
2009; Reddy and Murthy 2004; Reddy et al. 2004; Sharma et al. 2004; Strickley 2004; Sylvestre et al. 2011; Teshima et al. 2006; Thomas et al. 2012, 2013; Tomii 2002; Watanabe et al. 2006; Wu and Benet 2005; Xia et al. 2010; Zhang et al. 2006, 2008, 2013).

\section{Lipid nanosystems}

Lipid nanosystems including emulsions, liposomes, solidlipid nanoparticles, and lectin-modified solid lipids can be used to control the degradation and metabolism of the formulation and prolong systemic exposure. In addition, the selective delivery of pharmaceuticals can be improved and the pharmacological effect (e.g. anti-cancer effects in anticancer nanomedicines) can be enhanced by the increase of its accumulation in cancer tissues However, their disadvantages include rapid removal due to reticuloendothelial system (RES) uptake, limitation of administration routes, cytotoxicity risk due to low anti-genicity, and surfactant use for formulation (Devalapally et al. 2007; Kawabata et al. 2011; Liu and Fréchet 1999; Mora-Huertas et al. 2010).

Emulsions were formulated to increase oral $\mathrm{F}$ in both self-emulsifying and drug delivery systems, and several nanomedicines with emulsion formulations have been clinically used including cinnarizine, coenzyme Q10, cyclosporin A, halofantrine, and simvastatin. Inhalable dry emulsion of cyclosporin $\mathrm{A}$ is used to induce an 
anti-inflammatory effect in the lungs (Devalapally et al. 2007; Kawabata et al. 2011; Liu and Fréchet 1999; MoraHuertas et al. 2010).

Differences in liposome constituents in liposome formulations have been documented in several reports (Asthana et al. 2005; Barenholz 2012; Chaturvedi et al. 2013; Fanciullino et al. 2013; Feldman et al. 2012; Fetterly and Straubinger 2003; Hanafy et al. 2007; Hrkach et al. 2012; Jia et al. 2003; Jinno et al. 2006; Kaminskas et al. 2011, 2012; Kato et al. 2012; Kawabata et al. 2010; Kurmi et al. 2011; Larsen et al. 2013; Manvelian et al. 2012a, b; Manjunath and Venkateswarlu 2005; Matsumura et al. 2004; Morgen et al. 2012; Onoue et al. 2010a, b, 2011a, b, 2012a, b, 2013a, b; Pandey et al. 2005; Pathak and Nagarsenker 2009; Piao et al. 2008; Pepic' et al. 2004; Prajapati et al. 2009; Reddy and Murthy 2004; Reddy et al. 2004; Sharma et al. 2004; Strickley 2004; Sylvestre et al. 2011; Teshima et al. 2006; Thomas et al. 2012, 2013; Tomii 2002; Watanabe et al. 2006; Wu and Benet 2005; Xia et al. 2010; Zhang et al. 2006, 2008, 2013). Intravenous injectable solutions of amikacin and O-palmitoyl tilisolol in liposomes (Phospholipid/Chol) have been used for half-life extension, amphotericin B in liposomes (PC/ Chol/DSPG) shows decreased systemic exposure and RES uptake, and cytarabine/daunorubicin in liposomes (DSPC/ DSPG/Chol) has been used to reduce clearance. Pegylated liposome-treated doxorubicin results in increased distribution of doxotubicin to cancer tissues, and prednisolone in liposomes (PC/PG) or (PC/Chol/10\% DSPE-PEG2000) results in prolonged systemic exposure. Solid-lipid nanoparticles of azidothymidine result in increased permeability to the brain, those of clozapine result in increased systemic exposure due to clearance reduction, those of diclofenac developed as a transdermal preparation result in increased transdermal absorption, and those of lidocaine as a transdermal preparation result in longer duration of drug efficacy by regulating skin permeability. A lectinmodified solid-lipid $\mathrm{N}$ of insulin shows increased oral $\mathrm{F}$ (Asthana et al. 2005; Barenholz 2012; Chaturvedi et al. 2013; Fanciullino et al. 2013; Feldman et al. 2012; Fetterly and Straubinger 2003; Hanafy et al. 2007; Hrkach et al. 2012; Jia et al. 2003; Jinno et al. 2006; Kaminskas et al. 2011, 2012; Kato et al. 2012; Kawabata et al. 2010; Kurmi et al. 2011; Larsen et al. 2013; Manvelian et al. 2012a, b; Manjunath and Venkateswarlu 2005; Matsumura et al. 2004; Morgen et al. 2012; Onoue et al. 2010a, b, 2011a, b, 2012a, b, 2013a, b; Pandey et al. 2005; Pathak and Nagarsenker 2009; Piao et al. 2008; Pepic' et al. 2004; Prajapati et al. 2009; Reddy and Murthy 2004; Reddy et al. 2004; Sharma et al. 2004; Strickley 2004; Sylvestre et al. 2011; Teshima et al. 2006; Thomas et al. 2012, 2013; Tomii 2002; Watanabe et al. 2006; Wu and Benet 2005; Xia et al. 2010; Zhang et al. 2006, 2008, 2013).

\section{Micelles}

Micelles have advantages of high membrane permeability, and improved solubility and systemic exposure, but disadvantages of insufficient sustained release and cytotoxicity due to surfactant use (Devalapally et al. 2007; Kawabata et al. 2011; Liu and Fréchet 1999; Mora-Huertas et al. 2010). Block copolymeric micelles reduce clearance and increase systemic exposure of active pharmaceutical ingredients in intravenously administered formulations of camptothecin, doxorubicin, and paclitaxel. Block copolymer micelle allow direct administration to the eyeball increasing its efficacy. Self-micellizing solid dispersion of tranilast result in increased oral F (Asthana et al. 2005; Barenholz 2012; Chaturvedi et al. 2013; Fanciullino et al. 2013; Feldman et al. 2012; Fetterly and Straubinger 2003; Hanafy et al. 2007; Hrkach et al. 2012; Jia et al. 2003; Jinno et al. 2006; Kaminskas et al. 2011, 2012; Kato et al. 2012; Kawabata et al. 2010; Kurmi et al. 2011; Larsen et al. 2013; Manvelian et al. 2012a, b; Manjunath and Venkateswarlu 2005; Matsumura et al. 2004; Morgen et al. 2012; Onoue et al. 2010a, b, 2011a, b, 2012a, b, 2013a, b; Pandey et al. 2005; Pathak and Nagarsenker 2009; Piao et al. 2008; Pepic' et al. 2004; Prajapati et al. 2009; Reddy and Murthy 2004; Reddy et al. 2004; Sharma et al. 2004; Strickley 2004; Sylvestre et al. 2011; Teshima et al. 2006; Thomas et al. 2012, 2013; Tomii 2002; Watanabe et al. 2006; Wu and Benet 2005; Xia et al. 2010; Zhang et al. 2006, 2008, 2013).

\section{Polymeric nanoparticles}

Polymeric nanoparticles include ethyl cellulose/casein, PLGA (PLGA and alginate), PLA-PEG, hydrogel, albumin and chitosan analogs with characteristics of relatively stable drug release and prolonged duration of action. However, there are a few cases in which initial rupture is inhibited, or administration routes are limited. In particular, it is necessary to consider factors involved in elimination of nondegradable polymers from the body (Devalapally et al. 2007; Kawabata et al. 2011; Liu and Fréchet 1999; Mora-Huertas et al. 2010).

Polymeric nanoparticles with increased F include ethyl cellulose/casein nanoparticles with celecoxib, PLGA and alginate nanoparticle with clotrimazole/econazole or rifampicin, hydrogel nanoparticle with insulin, and an oral formulation of siRNA using chitosan analog nanoparticles. An docetaxel IV formulation using PLA-PEG nanoparticles showed a prolonged anticancer effect due to increased halflife. IV or IP formulations of LGA nanoparticles with doxorubicin have been reported to show reduced toxicity through prolongation of half-life and reduction of cardiac distribution. Half-life extension and $\mathrm{F}$ increase are also reported in the case of PLGA nanoparticles with glucagon (Asthana 
et al. 2005; Barenholz 2012; Chaturvedi et al. 2013; Fanciullino et al. 2013; Feldman et al. 2012; Fetterly and Straubinger 2003; Hanafy et al. 2007; Hrkach et al. 2012; Jia et al. 2003; Jinno et al. 2006; Kaminskas et al. 2011, 2012; Kato et al. 2012; Kawabata et al. 2010; Kurmi et al. 2011; Larsen et al. 2013; Manvelian et al. 2012a, b; Manjunath and Venkateswarlu 2005; Matsumura et al. 2004; Morgen et al. 2012; Onoue et al. 2010a, b, 2011a, b, 2012a, b, 2013a, b; Pandey et al. 2005; Pathak and Nagarsenker 2009; Piao et al. 2008; Pepic' $^{\prime}$ et al. 2004; Prajapati et al. 2009; Reddy and Murthy 2004; Reddy et al. 2004; Sharma et al. 2004; Strickley 2004; Sylvestre et al. 2011; Teshima et al. 2006; Thomas et al. 2012, 2013; Tomii 2002; Watanabe et al. 2006; Wu and Benet 2005; Xia et al. 2010; Zhang et al. 2006, 2008, 2013).

\section{Pharmacokinetic properties of nanomedicines}

Pharmacokinetic characteristics of various nanomedicines with different formulations are determined by particle size, shape (chemical structure), and surface chemical characteristics (FDA 2015). Nanomedicines with particle size less than $10 \mathrm{~nm}$ are removed by kidneys whereas those with particle size more than $10 \mathrm{~nm}$ are sometimes elongated and removed by the liver and/or the mononuclear-phagocyte system (MPS). The aim of regulating particle size in nanomedicines is to increase their retention in target tissues, and to remove them rapidly when distributed to non-target tissues. A protein corona is formed around nanomedicines by nonspecific protein adsorption in body, but this is prevented by materials such as polyethylene glycol (PEG) applied on the nano-particle through surface coating. Such protein adsorption induces protein denaturation, which may lead to protein aggregation or phagocytosis due to activated macrophages. Nanoparticle targeting based on chemical properties of nanoparticles and surface coatings comprises active and passive targeting. Passive targeting is defined as non-specific accumulation in disease tissue (usually cancer tissue). This is especially applicable to solid cancers in which targeting results in increased blood vessel and transporter permeations and retention (enhanced permeability and retention, EPR effect) of nanomedicines, and their increased accumulation in tumor tissues. Specific or active targeting is defined as selective transport of nanomedicines containing protein, antibody, or small molecule only to specific tissues and/or specific cells. This may occur via homing to overexpressed cell-surface receptors.

\section{Pharmacokinetic assessment of nanomedicine by regulatory agencies}

As mentioned above, a wide variety of nanomedicine have been developed and approved for use in clinical practice and there are also a number of nanomedicines in clinical trials.
As of 2016, 78 nanomedicines were on pharmaceutical markets across the world and 63 nanomedicines were approved as drugs or were in the approval process based on search results from 'http://www.clinicaltrial.gov'. It would be meaningful to summarize key considerations of the approval authorities and use this knowledge for the development and approval of nanomedicines.

\section{Food and Drug Administration (FDA)}

Nanoscale materials as defined by the US FDA include nanomaterials (materials used in the manufacture of nanomedicine, additives, etc.) and final products (nanomedicine). The particle size of such materials is typically $1-100 \mathrm{~nm}$ and such nanomedicines tend to result in increased bioavailability, decreased dose, improved drug efficacy, and decreased toxicity. Improvements in physical properties through effective formulation have led to improved solubility, dissolution rate, oral bioavailability, targeting to specific organs or cells, and/or improved dosage/convenience, leading to dose reduction with less adverse reactions due to the constituent active pharmaceutical ingredients or surfactants (FDA 2015).

\section{Status of nanomedicines approved by the FDA}

The FDA approved 51 nanomedicines by the year 2016, $40 \%$ of which were in clinical trials between 2014 and 2016 (Arnold et al. 2001; Benbrook 2015; Berges and Eligard 2005; Bobo et al. 2016; Desai et al. 2006; Duncan 2014; FDA 2006, 2014, 2015; Foss 2006; Foss et al. 2013; Fuentes et al. 2015; Green et al. 2006; Hann and Prentice 2001; Hu et al. 2012; Ing et al. 2016; James et al. 1994; Johnson et al. 1998; May and Li 2013; Möschwitzer and Müller 2006; Salah et al. 2010; Shegokar and Müller 2010; Taylor and Gercel-Taylor 2008; Ur Rehman et al. 2016; Wang-Gillam et al. 2016) (Table 4). Formulated nanomedicines approved by the FDA can be classified into polymer nanomedicines, micelles, liposomes, antibody-drug conjugates, protein nanoparticles, inorganic nanoparticles, hydrophilic polymers, and nanocrystals. Polymer nanomedicines are the simplest forms of nanomedicines and contain soft materials to increase solubility, biocompatibility, half-life and bioavailability as well as to control release of active pharmaceutical gradients from nanomedicines in body. In particular, Paxone $^{\circledR}$, Ulasta $^{\circledR}$, and PLEGRIDY ${ }^{\circledR}$ formulated with the use of poly(ethylene glycol) (PEG) are representative polymer nanomedicines resulting in increased half-life and bioavailability in in vivo. Micelles include Estrasorb ${ }^{\circledR}$, BIND-014, and CALAA-01 as controlled-release forms of lipophilic drugs. Liposomes have reduced toxicity and increased bioavailability, and include Onivyde ${ }^{\circledR}$, Doxil $^{\circledR}$, Visudyne ${ }^{\circledR}$, and Thermodox ${ }^{\circledR}$. Antibody-drug conjugates (ADCs) have been used to reduce drug cytotoxicity and improve solubility 


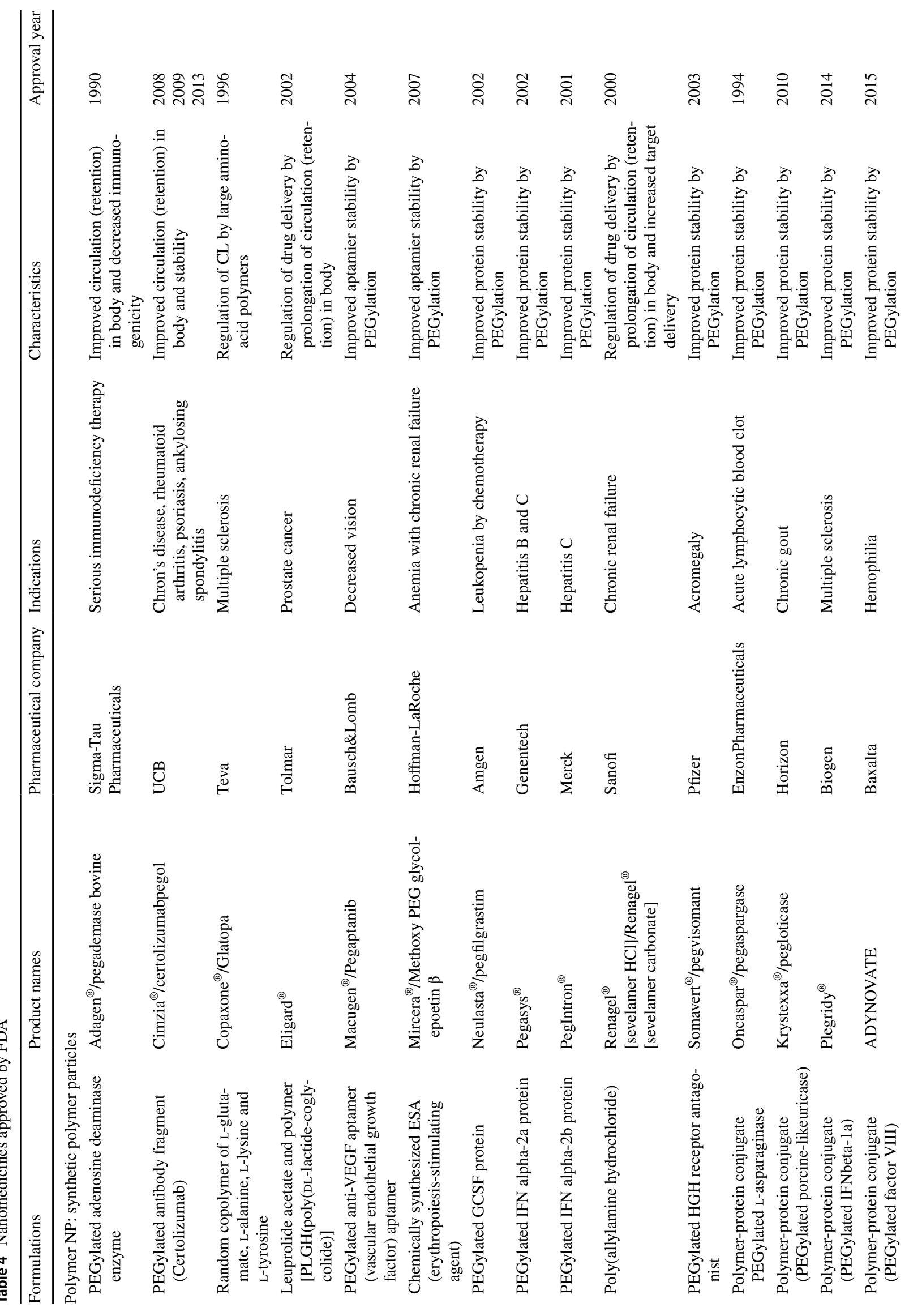




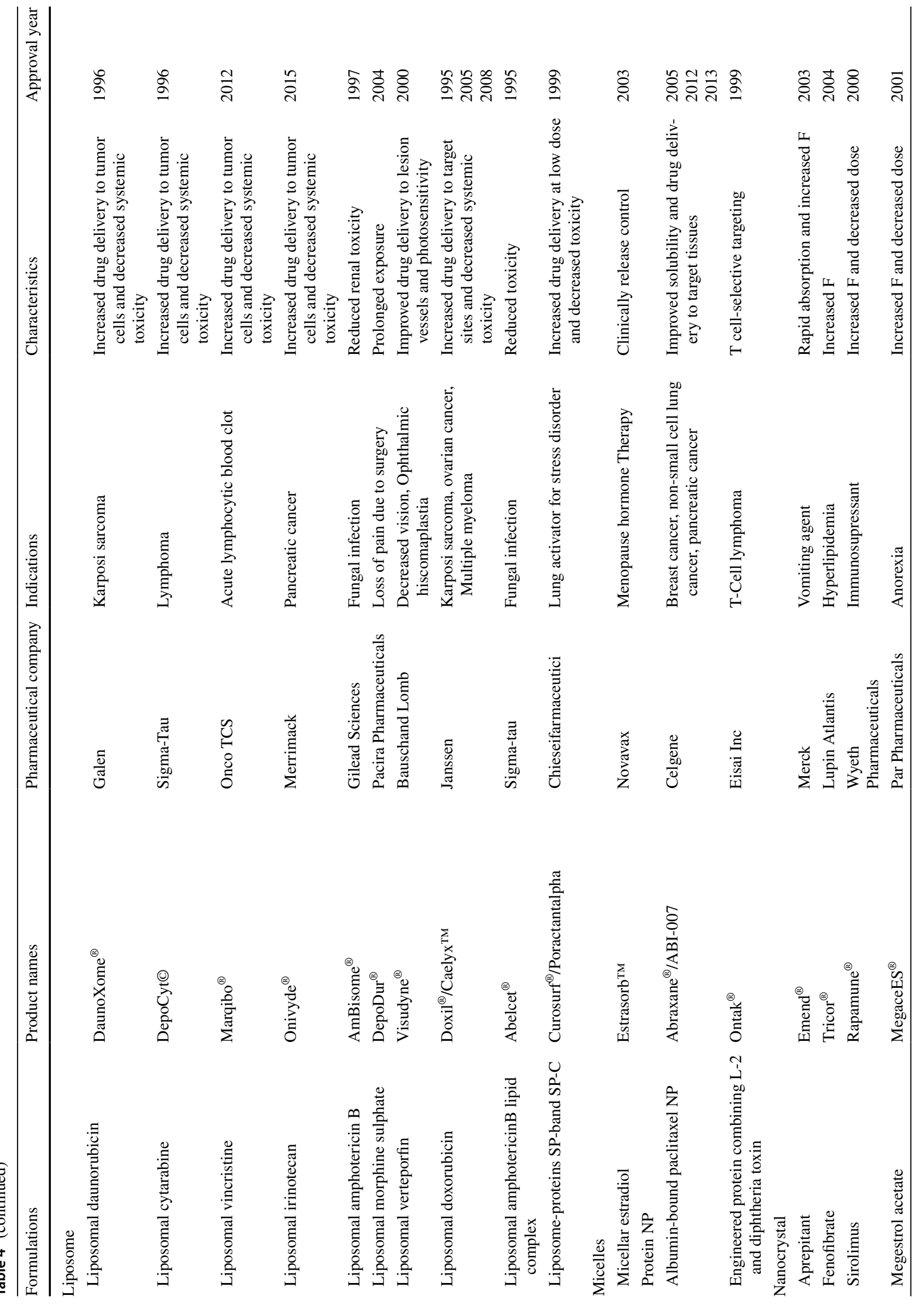




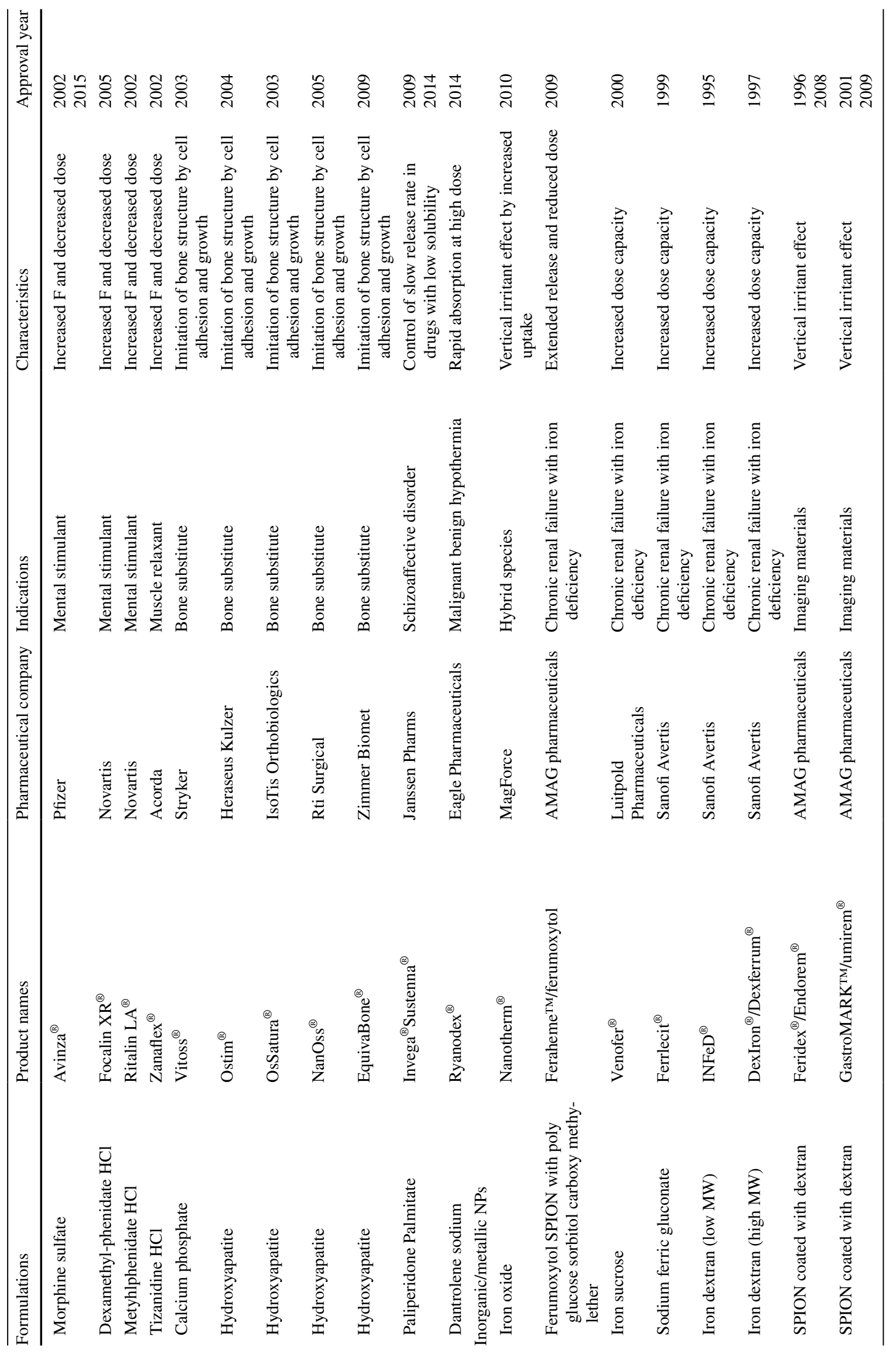


(PEGylation). ADCs are stable in blood and within targeted cancer cells and are expected to be released into intracellular or paracellular compartments after uptake. The pairing and linkage of antibody and drug are important, and are critical factors for their slow clearance and long halflife (approximately 3 and 4 days). Brentuximab emtasine is an example of an ADC nanomedicine which addresses safety issues by reducing toxicity of monomethyl auristane E. In this case, maleimide linkage and conjugation with thiolated antibody results in the release of only $2 \%$ monomethyl auristane E even 10 days after administration. ADCs with non-cleavable linkages such as those with tratuzumab are also available. Nanomedicines using protein nanoparticles include Abraxane ${ }^{\circledR}$, an albumin-bound paclitaxel, and Ontak ${ }^{\circledR}$, an engineered fusion protein, which consist of endogenous or engineered protein carriers. Inorganic nanoparticles in nanomedicine are drug formulations commonly used for treatment and/or imaging, in which metallic and metal oxide materials are used. Coating with hydrophilic polymers (dextran or sucrose) such as iron oxide is used for iron supplements including Venofer ${ }^{\circledR}$, Ferrlecit ${ }^{\circledR}$, INFed ${ }^{\circledR}$, Dexferrum $^{\circledR}$, and Feraheme ${ }^{\circledR}$, which show slow dissolution patterns after intravenous administration and less toxicity due to free iron in high dosage regimens. Because poor absorption of free iron is one of the reasons for increasing iron dosage resulting in severe toxicity, an iron oxide nanomedicine formulation with iron supplementation is clinically meaningful. Inorganic nanomedicines using gold are based on thermal and surface chemistry of gold, and it have not yet been approved by the FDA. Several clinical investigations using nanomedicines formulated with gold have been conducted. CYP-6091 containing colloidal gold with recombinant human tumor necrosis factor rhTNF is in a phase 2 trial, NBTXR3 and PEP503 are radio enhancers containing hifnium metal oxide for brain tumor treatment and inorganic silica nanoparticles for fluorescence-based cancer imaging, respectively, and are in phase 1 trials. Nanocrystal formulations increase nanoscale dimensions and improve dissolution and solubility and include Rapamune ${ }^{\circledR}$, Tricor ${ }^{\circledR}$, Emend $^{\circledR}$, and Megace $\mathrm{ES}^{\circledR}$.

\section{Suggested considerations for the evaluation of nanomedicines by the FDA}

Based on guidelines and reports from the FDA, considerations for evaluation of nanomedicines are as follows. Evaluation of nano-formulation properties of nanomedicines comprises evaluating physicochemical properties of the nanomaterials, constituents and proportions of the nanomaterials, and quality and manufacturing of the nanomaterials (Eifler and Thaxton 2011; FDA 2010). First, pharmacokinetics of nanomedicines are assessed in the context of their systemic exposure considering (1) rate and amount of absorption and retention in circulation based on blood concentration over time, (2) relationship between prolongation of half-life and whole body exposure duration, and (3) bioavailability changes (Eifler and Thaxton 2011; FDA 2010, 2015). Second, assessment of nanomedicine distribution to blood and tissue is recommended to be done based on apparent volume of distribution, and distribution or accumulation to positive targeting sites based on time-dependent changes. Third, in the context of metabolism, it is important to evaluate whether decomposition or metabolism of nano-formulations or their active pharmaceutical ingredients occur. Fourth, elimination of raw materials used in nano-formulations, and products from decomposition and/or metabolism of nano-formulations and their active pharmaceutical ingredients are recommended for evaluation. The accumulation of nano-formulations in target tissues and elimination through MPS are also investigated. Finally, toxicity assessment of nanomedicines needs to be conducted.

\section{EMA}

In 2011, the EMA defined nanomedicines as drugs composed of nanomaterials $1-100 \mathrm{~nm}$ in size, and these are classified into liposomes, nanoparticles, magnetic NPs, gold NPs, quantum dots, dendrimers, polymeric micelles, viral and non-viral vectors, carbon nanotubes, and fullerenes (EFSA 2011; EMA 2015a).

\section{Status of nanomedicines approved by the EMA}

The EMA has approved 8 of the 11 commercially available nanomedicine drugs developed as first-generation nanomedicines (such as liposomes or iron-containing formulations), and three of them were withdrawn. Investigations were conducted to establish the scientific basis for efficacy and safety of 12 nanomedicines, and were evaluated via the European Medicines Agency (EMA) approval process. Following this initial process, 48 nano medicines or imaging materials are currently in clinical trials (Phase 1-Phase 3) in the EU. In addition, preclinical trials are underway for a number of nanomedicine products (Draca et al. 2013; Ehmann et al. 2013; Hafner et al. 2014; Lawrence and Rees 2000; Ling et al. 2013; Shegokar and Müller 2010) (Table 5).

\section{Suggesting points for the evaluation of nanomedicines in EMA}

EMA presents that pharmacokinetic and pharmacodynamic properties of nanomedicines were determined by chemical composition and physicochemical properties. So, EMA suggest to consider six possibilities to evaluate nanomedicines considering the chemical composition and physicochemical properties (EFSA 2011; TGA 2016) 
Table 5 Nanomedicines approved by EMA

\begin{tabular}{|c|c|c|c|c|c|}
\hline Formulations & API & Product name & $\begin{array}{l}\text { Pharmaceutical } \\
\text { company }\end{array}$ & Administration route & Indications \\
\hline \multirow[t]{5}{*}{ Nanocrystals } & Aprepitan & Emend $^{\circledR}$ & $\begin{array}{l}\text { Merck Sharp and } \\
\text { Dohme BV }\end{array}$ & Capsule & Vomiting after surgery \\
\hline & Fenofibrate & $\begin{array}{l}\text { Tricor }^{\circledR} / \text { Lipanthyl }^{\circledR} / \\
\text { Lipidil }^{\circledR}\end{array}$ & Recipharm, FR & Tablet & Hyperlipidemia \\
\hline & Olanzapine & Zypadhera $^{\circledR}$ & Lilly Pharma & Powder/solvent & Schizophrenia \\
\hline & Paliperidone & Xeplion $^{\circledR}$ & $\begin{array}{l}\text { Janssen Pharmaceu- } \\
\text { tica NV }\end{array}$ & $\begin{array}{l}\text { Prolonged release } \\
\text { suspension for } \\
\text { injection (im) }\end{array}$ & Schizophrenia \\
\hline & Sirolimus & Rapamune $^{\circledR}$ & $\begin{array}{l}\text { Pfizer Ireland Phar- } \\
\text { maceuticals, IE }\end{array}$ & Tablet & $\begin{array}{l}\text { Kidney transplantation } \\
\text { rejection }\end{array}$ \\
\hline \multirow[t]{3}{*}{ Nanoemulsions } & Cyclosporine & Norvir $^{\circledR}$ & $\begin{array}{l}\text { Aesica Queenborough } \\
\text { Ltd }\end{array}$ & Soft capsules & $\begin{array}{l}\text { HIV infection, kidney } \\
\text { transplantation rejec- } \\
\text { tion }\end{array}$ \\
\hline & $\begin{array}{l}\text { Pegaspargase (mPEG- } \\
\text { asparaginase) }\end{array}$ & Oncaspar $^{\circledR}$ & $\begin{array}{l}\text { Sigma-tau Arzneimit- } \\
\text { tel GmbH }\end{array}$ & Solution (iv/im) & $\begin{array}{l}\text { Acute lymphocytic } \\
\text { leukemia }\end{array}$ \\
\hline & Sevelamer & Renagel $^{\circledR} /$ Renvela $^{\circledR}$ & Genzyme Ltd & Tablet & $\begin{array}{l}\text { Dialysis, hyperphos- } \\
\text { phatemia }\end{array}$ \\
\hline \multirow{7}{*}{$\begin{array}{l}\text { Polymer-protein con- } \\
\text { jugates }\end{array}$} & Amphotericin B & AmBisome $^{\circledR}$ & Gilead Sciences & Suspension (iv) & Fungal infection \\
\hline & $\begin{array}{l}\text { Certolizumabpegol } \\
\text { (PEG-anti-TNFFab) }\end{array}$ & Cimzia $^{\mathrm{TM}}$ & UCB Pharma SA & Solution (sc) & Rheumatoid arthritis \\
\hline & $\begin{array}{l}\text { Methoxypolyethylene } \\
\text { glycol-epoetin beta }\end{array}$ & Mircera $^{\circledR}$ & Roche Pharma & Solution (iv/sc) & $\begin{array}{l}\text { Anemia, chronic renal } \\
\text { failure }\end{array}$ \\
\hline & $\begin{array}{l}\text { Pegfilgrastim (PEG- } \\
\text { rhGCSF) }\end{array}$ & Neulasta $^{\circledR}$ & Amgen Technology & Solution (sc) & $\begin{array}{l}\text { Leukopenia by chemo- } \\
\text { therapy }\end{array}$ \\
\hline & $\begin{array}{l}\text { Peginterferonalpha-2a } \\
\text { (mPEG-interferon } \\
\text { alpha-2a) }\end{array}$ & Pegasys $^{\circledR}$ & Roche Pharma & Solution (sc) & $\mathrm{HBV} / \mathrm{HCV}$ infection \\
\hline & $\begin{array}{l}\text { Peginterferonalpha-2b } \\
\text { (mPEG-interferon } \\
\text { alpha-2b) }\end{array}$ & PegIntron $^{\circledR}$ & Schering-Plough & $\begin{array}{l}\text { Solution for injection } \\
\text { (sc) }\end{array}$ & HIV inflammation \\
\hline & $\begin{array}{l}\text { Pegvisomant (PEG- } \\
\text { HGH antagonist) }\end{array}$ & Somavert $^{\circledR}$ & Pfizer Manufacturing & $\begin{array}{l}\text { Solution for injection } \\
\text { (sc) }\end{array}$ & Peripheral hypertrophy \\
\hline \multirow[t]{9}{*}{ Liposomes } & Cytarabine & DepoCyt $^{\circledR}$ & Almac Pharma & $\begin{array}{l}\text { Suspension (intrathe- } \\
\text { cal) }\end{array}$ & Brain cancer \\
\hline & Daunorubicin & DaunoXome ${ }^{\circledR}$ & Gilead Sciences Ltd & Suspension (iv) & $\begin{array}{l}\text { Kaposi sarcoma by } \\
\text { HIV }\end{array}$ \\
\hline & Doxorubicin & Myocet $^{\circledR}$ & GP-Pharm & Suspension (iv) & Breast cancer \\
\hline & Doxorubicin & Caelyx ${ }^{\circledR}$ & $\begin{array}{l}\text { Janssen Pharmaceu- } \\
\text { tical }\end{array}$ & Suspension (iv) & $\begin{array}{l}\text { Breast cancer, ovar- } \\
\text { ian cancer, Kaposi } \\
\text { sarcoma }\end{array}$ \\
\hline & Mifamurtide & Mepact $^{\circledR}$ & Takeda & Suspension (iv) & Myosarcoma \\
\hline & Morphine & DepoDur $^{\circledR}$ & Almac Pharma & Suspension(epidural) & Pain \\
\hline & Paclitaxel & Abraxane $^{\circledR}$ & Celgene & $\begin{array}{l}\text { Powder for suspen- } \\
\text { sion }\end{array}$ & Breast cancer \\
\hline & Propofol & $\begin{array}{r}\text { Diprivan }{ }^{\circledR} / \text { Propofol- } \\
\text { Lipuro }^{\circledR} / \text { Propofol }^{\circledR}\end{array}$ & Astra Zeneca & Emulsion (iv) & Anesthesia \\
\hline & Verteporfin & Visudyne $^{\circledR}$ & $\begin{array}{l}\text { Novartis Pharma } \\
\text { GmbH, Nürnberg }\end{array}$ & Suspension (iv) & $\begin{array}{l}\text { Decreased vision, } \\
\text { myopia }\end{array}$ \\
\hline \multirow[t]{2}{*}{ Nanoparticles } & $\begin{array}{l}\text { Inactivated hepatitis } \\
\text { A virus }\end{array}$ & Epaxal $^{\circledR}$ & Crucell & Suspension (iv) & Hepatitis A vaccines \\
\hline & $\begin{array}{l}\text { 90Y-ibritumomab } \\
\text { tiuxetan }\end{array}$ & Zevalin $^{\circledR}$ & Bayer Pharma & Solution (iv) & Lymphoma \\
\hline
\end{tabular}


Table 5 (continued)

\begin{tabular}{|c|c|c|c|c|c|}
\hline Formulations & API & Product name & $\begin{array}{l}\text { Pharmaceutical } \\
\text { company }\end{array}$ & Administration route & Indications \\
\hline \multirow[t]{2}{*}{ Virosomes } & $\begin{array}{l}\text { Adjuvanted influenza } \\
\text { vaccine }\end{array}$ & Inflexal $^{\circledR} \mathrm{V}$ & Crucell & Suspension (iv) & Influenza vaccines \\
\hline & $\begin{array}{l}\text { Glatiramer } \\
\text { (Glu,Ala,Tyr,Lys } \\
\text { copolymer) }\end{array}$ & Copaxone $^{\circledR}$ & Teva Pharmaceuticals & Solution (sc) & Multiple sclerosis \\
\hline Polymeric drugs & $\begin{array}{l}\text { Sodium ferric gluco- } \\
\text { nate }\end{array}$ & Ferrlecit $^{\circledR}$ & Aventis Pharma & Solution (iv) & $\begin{array}{l}\text { Anemia with iron } \\
\text { deficiency }\end{array}$ \\
\hline \multirow[t]{5}{*}{ Nanocomplex } & Ferric carboxymaltose & Ferinject $^{\circledR}$ & Vifor & Solution (iv) & Iron deficiency \\
\hline & Ferumoxytol & Rienso $^{\circledR}$ & Takeda & Solution (iv) & $\begin{array}{l}\text { Anemia with iron } \\
\text { deficiency, chronic } \\
\text { renal failure }\end{array}$ \\
\hline & $\begin{array}{l}\text { Iron sucrose [iron(III)- } \\
\text { hydroxidesucrose } \\
\text { complex] }\end{array}$ & Visudyne $^{\circledR}$ & Novartis & Solution (iv) & Iron deficiency \\
\hline & Iron(III) isomaltoside & Monofer $^{\circledR}$ & Pharmacosmos & Solution (iv) & Iron deficiency \\
\hline & $\begin{array}{l}\text { Iron(III)-hydroxide } \\
\text { dextran complex }\end{array}$ & Ferrisat $^{\circledR} /$ Cosmofer $^{\circledR}$ & Pharmacosmos & Solution (iv) & Iron deficiency \\
\hline
\end{tabular}

including (1) nano-formulations are unstable at the time of manufacture and are converted into non-nanosized form, (2) the state of conversion into non-nanosized form when the drug substance in the manufacturing site is present as a matrix, (3) conversion to non-nanosized forms due to lack of bio-similarity under in vitro non-stable conditions, (4) conversion from nano-forms to non-nanosized forms during toxicity assessment (5) co-existence of nano forms and non-nano forms at the in vivo administration site, and (6) existence of the nano form in biological samples and tissues after absorption. In view of these various considerations for nanomedicine evaluation, EMA suggested the need to discuss the following aspects for the evaluation of nanomedicines (EFSA 2011; EMA 2015a, b; Ehmann et al. 2013; TGA 2016). Overall, physicochemical properties, stability, and functionality of nanomedicines should be evaluated. To this end, interactions and reactivity with biointerfaces due to coatings or additives in the final nanomedicines, suitability of biomarkers of in vivo functionality of nanomedicines, in vivo distribution and bio-persistence of nanomedicines, long-term safety of decomposition products, and adequacy of dose and dose interval settings have emerged as key factors for the evaluation process. Notably, liposome formulations, iron-based formulations, and nanocrystal formulations which can be considered first-generation nanomedicines and have already been marketed and used, have proved their effectiveness and safety over a long period. Based on this status, evaluation methods for approval of secondgeneration nanomedicines have been suggested for consideration (Ehmann et al. 2013; EMA 2013a, b, EMA 2015b).

\section{Future perspectives on nanomedicines considering their pharmacokinetic properties}

Given the considerations for development and use of nanomedicines, indispensable steps to attain clinical significance include assessment of the nature of formulations, pharmacokinetic properties, and the approval process for nanomedicines. Therefore, based on recent trends in nanomedicine development and guidelines of the FDA and EMA, we propose a simple algorithm to guide the recommended ADME evaluations of nanomedicines (Fig. 1). In the proposed algorithm, stability in the manufacturing process and simulated human conditions determine whether ADME properties of the drugs of interest are assessed or not. Assessment varies based on administration routes and distribution. For example, evaluation varies based on whether orally administered nanomedicines are found in nano forms or non-nano forms in the gastro-intestinal tract. Thus, the proposed algorithm provides critical and practical checkpoints in nanomedicine development and assessment.

Acknowledgements This research was supported by a Grant (16173MFDS542) from Ministry of Food and Drug Safety in 2016.

\section{Compliance with ethical standards}

Conflict of interest These authors (Young Hee Choi and Hyo-Kyung Han) declare that they have no conflict of interest.

Open Access This article is distributed under the terms of the Creative Commons Attribution 4.0 International License (http://creativeco 


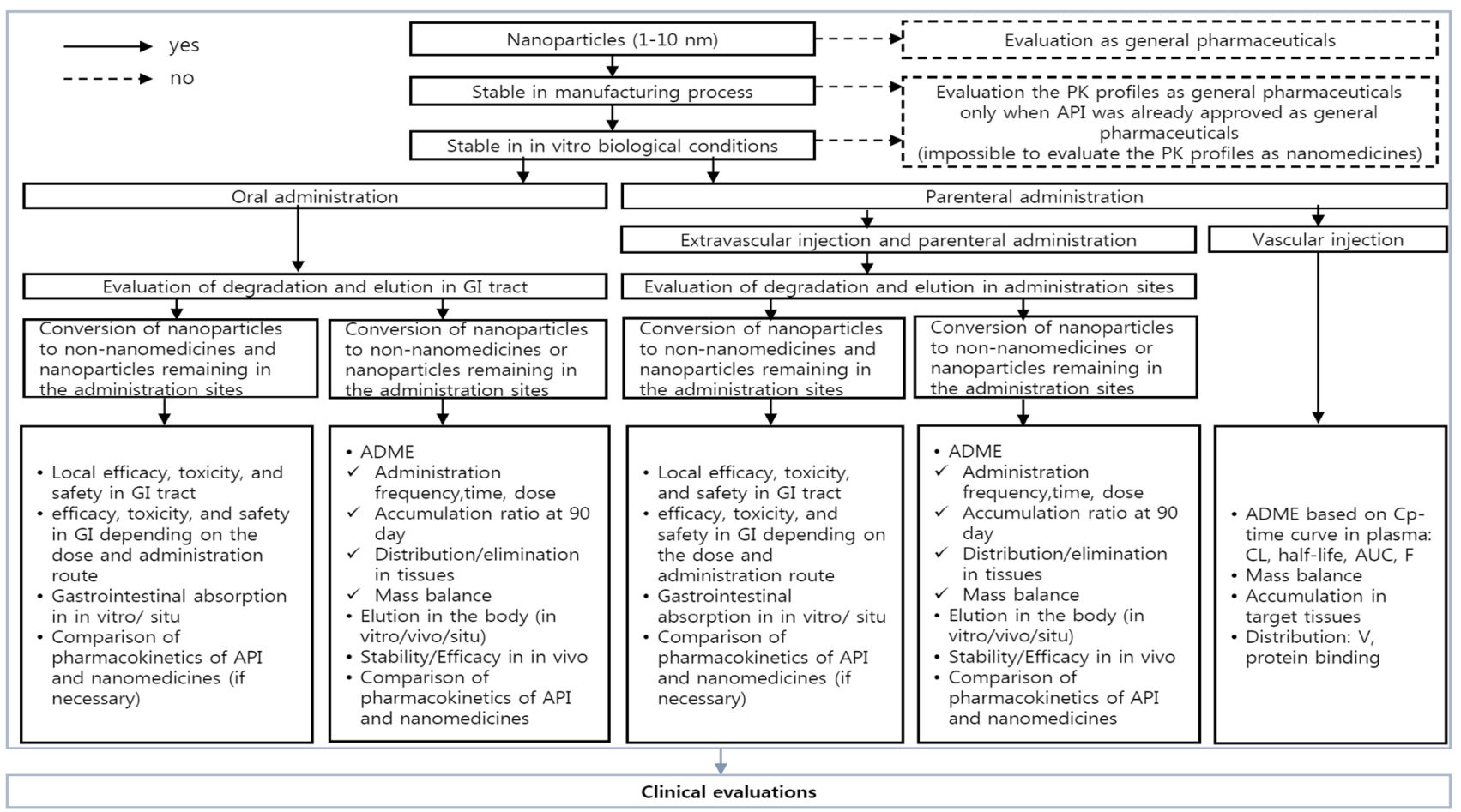

Fig. 1 A proposed new algorithm to assess ADME of nanomedicines

mmons.org/licenses/by/4.0/), which permits use, duplication, adaptation, distribution and reproduction in any medium or format, as long as you give appropriate credit to the original author(s) and the source, provide a link to the Creative Commons license and indicate if changes were made.

\section{References}

Arnold J, Kilmartin D, Olson J, Neville S, Robinson K, Laird A (2001) Verteporfin therapy of subfoveal choroidal neovascularization in age-related macular degeneration: two-year results of a randomized clinical trial including lesions with occult with no classic choroidal neovascularization-verteporfin in photodynamic therapy report 2. Am J Ophthalmol 131:541-560

Asthana A, Chauhan AS, Diwan PV, Jain NK (2005) Poly(amidoamine) (PAMAM) dendritic nanostructures for controlled site-specific delivery of acidic anti-inflammatory active ingredient. AAPS PharmSciTech 6:E536-E542

Barenholz Y (2012) Doxil®— the first FDA-approved nano-drug: lessons learned. J Control Release 160:117-134

Benbrook DM (2015) Biotechnology and biopharmaceuticals: transforming proteins and genes into drugs, 2nd edition. Clinic infect Dis: Off Publ Infect Dis Soc Am 60:331-332

Berges R, Eligard R (2005) Pharmacokinetics, effect on testosterone and PSA levels and tolerability. Eur Urol Suppl 4:20-25

Bobo D, Robinson KJ, Islam J, Thurecht KJ, Corrie SR (2016) Nanoparticle-based medicines: a review of FDA-approved materials and clinical trials to date. Pharm Res 33:2373-2387

Bur M, Henning A, Hein S, Schneider M, Lehr CM (2009) Inhalative nanomedicine-opportunities and challenges. Inhal Toxicol 1:S137-S143
Charlene MD, Luisa MR, Peter CS (2014) Nanomedicines for cancer therapy: state-of-the-art and limitations to pre-clinical studies that hinder future developments. Front Chem 2:69

Chaturvedi K, Ganguly K, Nadagouda MN, Aminabhavi TM (2013) Polymeric hydrogels for oral insulin delivery. J Control Release 165:129-138

Dawidczyk CM, Kim C, Park JH, Russell LM, Lee KH, Pomper MG, Searson PC (2014) State-of-the-art in design rules for drug delivery platforms: lessons learned from FDA-approved nanomedicines. J Control Release 10:133-144

De Jong WH, Borm PJ (2008) Drug delivery and nanoparticles: applications and hazards. Int J Nanomed 3:133-149

Des Rieux A, Fievez V, Garinot M, Schneider YJ, Préat V (2006) Nanoparticles as potential oral delivery systems of proteins and vaccines: a mechanistic approach. J Control Release 116:1-27

Desai N, Trieu V, Yao ZW, Louie L, Ci S, Yang A (2006) Increased antitumor activity, intratumor paclitaxel concentrations, and endothelial cell transport of Cremophor-free, albumin-bound paclitaxel, ABI-007, compared with Cremophor-based paclitaxel. Clin Cancer Res 12:1317-1324

Devalapally H, Chakilam A, Amiji MM (2007) Role of nanotechnology in pharmaceutical product development. J Pharm Sci 96:2547-2565

Draca N, Lazic R, Simic P, Dumic-Cule I, Luetic AT, Gabric N (2013) Potential beneficial role of sevelamer hydrochloride in diabetic retinopathy. Med Hypotheses 80:431-435

Duncan R (2014) Polymer therapeutics: top 10 selling pharmaceuticals-what next? J Control Release 190:371-380

Ehmann F, Sakai-Kato K, Duncan R, Hernán P, de la Ossa D, Pita R, Vidal JM, Kohli A, Tothfalusi L, Sanh A, Tinton S et al (2013) Next-generation nanomedicines and nanosimilars: EU regulators' initiatives relating to the development and evaluation of nanomedicines. Nanomedicine 8:849-856 
Eifler AC, Thaxton CS (2011) Nanoparticle therapeutics: FDA approval, clinical trials, regulatory pathways, and case study. Methods Mol Biol 726:325-338

European Food Safety Authority (2011) Guidance on the risk assessment of the application of nanoscience and nanotechnologies in the food and feed chain. EFSA J 9:2140

European Medicines Agency (2013a) Reflection paper on surface coatings: general issues for consideration regarding parenteral administration of coated nanomedicine products. http://www. ema.europa.eu/docs/en_GB/document_library/Scientific_guideline/2013/08/WC500147874.pdf

European Medicines Agency (2013b) Reflection paper on the development of 5 block copolymer micelle medicinal products. http:// www.ema.europa.eu/docs/en_GB/document_library/Scientific_ guideline/2013/02/WC500138390.pdf

European Medicines Agency (2015a) Nanomedicines: EMA experience and perspective. http://www.euronanoforum2015.eu/wpcontent/uploads/2015/06/2_NanomedicinesEMA-experienceperspective_DoloresHernan_10042015.pdf

European Medicines Agency (2015b) Reflection paper on the data requirements for intravenous iron-based nano-colloidal products developed with reference to an innovator medicinal product. http://www.ema.europa.eu/docs/en_GB/document_library/ Scientific_guideline/2015/03/WC500184922.pdf

Fanciullino R, Ciccolini J, Milano G (2013) Challenges, expectations and limits for nanoparticles-based therapeutics in cancer: a focus on nano-albumin-bound drugs. Crit Rev Oncol Hematol 88:504-513

FDA (2006) FDA considerations for regulation of nanomaterial containing products

FDA (2010) A FDA perspective on nanomedicine current initiative in the US

FDA (2014) Guidance for industry considering whether an FDA-regulated product involves the application of nanotechnology. http:// www.fda.gov/RegulatoryInformation/Guidances/ucm257698. htm

FDA (2015) Liposome drug products guidance for industry. http:// www.fda.gov/Drugs/GuidanceComplianceRegulatoryInformation/Guidances/default.htm

Feldman EJ, Kolitz JE, Trang JM, Liboiron BD, Swenson CE, Chiarella MT, Mayer LD, Louie AC, Lancet JE (2012) Pharmacokinetics of CPX-351; a nano-scale liposomal fixed molar ratio formulation of cytarabine: daunorubicin, in patients with advanced leukemia. Leuk Res 36:1283-1289

Fetterly GJ, Straubinger RM (2003) Pharmacokinetics of paclitaxelcontaining liposomes in rats. AAPS Pharm Sci 5:E32

Foss F (2006) Clinical experience with Denileukin Diftitox (ONTAK). Semin Oncol 33(1 Supplement 3):S11-S16

Foss FM, Sjak-Shie N, Goy A, Jacobsen E, Advani R, Smith MR (2013) A multicenter phase II trial to determine the safety and efficacy of combination therapy with denileukin diftitox and cyclophosphamide, doxorubicin, vincristine and prednisone in untreated peripheral T-cell lymphoma: the CONCEPT study. Leuk lymphoma 54:1373-1379

Francis MF, Cristea M, Winnik FM (2005) Exploiting the vitamin B12 pathway to enhance oral drug delivery via polymeric micelles. Biomacromolecules 6:2462-2467

Fuentes AC, Szwed E, Spears CD, Thaper S, Dang LH, Dang NH (2015) Denileukin diftitox (Ontak) as maintenance therapy for peripheral T-Cell lymphomas: three cases with sustained remission. Case Rep Oncol Med 2015:123756

Green MR, Manikhas GM, Orlov S, Afanasyev B, Makhson AM, Bhar P, Hawkins MJ (2006) Abraxane((R)), a novel Cremophor((R))free, albuminbound particle form of paclitaxel for the treatment of advanced non-small-cell lung cancer. Ann Oncol $17: 1263-1268$
Hafner A, Lovrić J, Lakoš GP, Pepić I (2014) Nanotherapeutics in the EU: an overview on current state and future directions. Int J Nanomed 19:1005-1023

Hanafy A, Spahn-Langguth H, Vergnault G, Grenier P, Tubic Grozdanis M, Lenhardt T, Langguth P (2007) Pharmacokinetic evaluation of oral fenofibrate nanosuspensions and SLN in comparison to conventional suspensions of micronized drug. Adv Drug Deliv Rev 59:419-426

Hann IM, Prentice HG (2001) Lipid-based amphotericin B: a review of the last 10 years of use. Int J Antimicrob Agents 17:161-169

Hrkach J, Von Hoff D, Mukkaram Ali M, Andrianova E, Auer J, Campbell T, De Witt D, Figa M, Figueiredo M, Horhota A et al (2012) Preclinical development and clinical translation of a PSMA-targeted docetaxel nanoparticle with a differentiated pharmacological profile. Sci Transl Med 4:128-139

Hu X, Miller L, Richman S, Hitchman S, Glick G, Liu S, Zhu Y, Crossman M, Nestorov I, Gronke RS et al (2012) A novel PEGylated interferon Beta-1a for multiple sclerosis: safety, pharmacology, and biology. J Clin Pharmacol 52:798-808

Ing M, Gupta N, Teyssandier M, Maillere B, Pallardy M, Delignat S, Lacroix-Desmazes S (2016) Immunogenicity of long-lasting recombinant factor VIII products. Cell Immunol 301:40-48

Jain A, Jain SK (2008) In vitro and cell uptake studies for targeting of ligand anchored nanoparticles for colon tumors. Eur J Pharm Sci 35:404-416

James ND, Coker RJ, Tomlinson D, Harris JR, Gompels M, Pinching AJ (1994) Liposomal doxorubicin (Doxil): an effective new treatment for Kaposi's sarcoma in AIDS. Clin Oncol 6:294-296

Jia L, Wong H, Wang Y, Garza M, Weitman SD (2003) Carbendazim: disposition, cellular permeability, metabolite identification, and pharmacokinetic comparison with its nanoparticle. J Pharm Sci 92:161-172

Jinno J, Kamada N, Miyake M, Yamada K, Mukai T, Odomi M, Toguchi H, Liversidge GG, Higaki K, Kimura T (2006) Effect of particle size reduction on dissolution and oral absorption of a poorly water-soluble drug, cilostazol, in beagle dogs. J Control Release 111:56-64

Johnson KP, Brooks BR, Cohen JA, Ford CC, Goldstein J, Lisak RP, Myers LW, Panitch HS, Rose JW, Schiffer RB et al (1998) Extended use of glatiramer acetate (Copaxone) is well tolerated and maintains its clinical effect on multiple sclerosis relapse rate and degree of disability. Neurology 50:701-708

Kaminskas LM, Kelly BD, McLeod VM, Sberna G, Boyd BJ, Owen DJ, Porter CJ (2011) Capping methotrexate $\alpha$-carboxyl groups enhances systemic exposure and retains the cytotoxicity of drug conjugated PEGylated polylysine dendrimers. Mol Pharm 8:338-349

Kaminskas LM, McLeod VM, Kelly BD, Sberna G, Boyd BJ, Williamson M, Owen DJ, Porter CJ (2012) A comparison of changes to doxorubicin pharmacokinetics, antitumor activity, and toxicity mediated by PEGylated dendrimer and PEGylated liposome drug delivery systems. Nanomedicine 8:103-111

Kato K, Chin K, Yoshikawa T, Yamaguchi K, Tsuji Y, Esaki T, Sakai K, Kimura M, Hamaguchi T, Shimada Y et al (2012) Phase II study of NK105, a paclitaxel-incorporating micellar nanoparticle, for previously treated advanced or recurrent gastric cancer. Invest New Drugs 30:1621-1627

Kawabata Y, Yamamoto K, Debari K, Onoue S, Yamada S (2010) Novel crystalline solid dispersion of tranilast with high photostability and improved oral bioavailability. Eur J Pharm Sci 39:256-262

Kawabata Y, Wada K, Nakatani M, Yamada S, Onoue S (2011) Formulation design for poorly water-soluble drugs based on biopharmaceutics classification system: basic approaches and practical applications. Int J Pharm 420:1-10 
Kurmi BD, Gajbhiye V, Kayat J, Jain NK (2011) Lactoferrin-conjugated dendritic nanoconstructs for lung targeting of methotrexate. J Pharm Sci 100:2311-2320

Larsen AT, Ohlsson AG, Polentarutti B, Barker RA, Phillips AR, Abu-Rmaileh R, Dickinson PA, Abrahamsson B, Ostergaard J, Müllertz A (2013) Oral bioavailability of cinnarizine in dogs: relation to SNEDDS droplet size, drug solubility and in vitro precipitation. Eur J Pharm Sci 48:339-350

Lawrence MJ, Rees GD (2000) Microemulsion-based media as novel drug delivery systems. Adv Drug Deliv Rev 45:89-121

Ling H, Luoma JT, Hilleman D (2013) A review of currently available fenofibrate and fenofibric acid formulations. Cardiol Res 4:47-55

Liu M, Fréchet JM (1999) Designing dendrimers for drug delivery. Pharm Sci Technol Today 2:393-401

Liu W, Yang XL, Ho WS (2011) Preparation of uniform-sized multiple emulsions and micro/nano particulates for drug delivery by membrane emulsification. J Pharm Sci 100:75-93

Manjunath K, Venkateswarlu V (2005) Pharmacokinetics, tissue distribution and bioavailability of clozapine solid lipid nanoparticles after intravenous and intraduodenal administration. J Control Release 107:215-228

Manvelian G, Daniels S, Gibofsky A (2012a) The pharmacokinetic parameters of a single dose of a novel nano-formulated, lowerdose oral diclofenac. Postgrad Med 124:117-123

Manvelian G, Daniels S, Altman R (2012b) A phase I study evaluating the pharmacokinetic profile of a novel, proprietary, nano-formulated, lower-dose oral indomethacin. Postgrad Med 124:197-205

Matsumura Y, Hamaguchi T, Ura T, Muro K, Yamada Y, Shimada Y, Shirao K, Okusaka T, Ueno H, Ikeda M, Watanabe N (2004) Phase I clinical trial and pharmacokinetic evaluation of NK911, a micelle-encapsulated doxorubicin. Br J Cancer 91:1775-1781

May JP, Li S-D (2013) Hyperthermia-induced drug targeting. Exp Opin Drug Deliv 10:511-527

Mora-Huertas CE, Fessi H, Elaissari A (2010) Polymer-based nanocapsules for drug delivery. Int J Pharm 385:113-1142

Morgen M, Bloom C, Beyerinck R, Bello A, Song W, Wilkinson K, Steenwyk R, Shamblin S (2012) Polymeric nanoparticles for increased oral bioavailability and rapid absorption using celecoxib as a model of a low-solubility, high-permeability drug. Pharm Res 29:427-440

Mori S, Matsuura A, Rama Prasad YV, Takada K (2004) Studies on the intestinal absorption of low molecular weight heparin using saturated fatty acids and their derivatives as an absorption enhancer in rats. Biol Pharm Bull 27:418-421

Möschwitzer J, Müller RH (2006) New method for the effective production of ultrafine drug nanocrystals. J Nanosci Nanotechnol 6:3145-3153

Onoue S, Takahashi H, Kawabata Y, Seto Y, Hatanaka J, Timmermann B, Yamada S (2010a) Formulation design and photochemical studies on nanocrystal solid dispersion of curcumin with improved oral bioavailability. J Pharm Sci 99:1871-1881

Onoue S, Uchida A, Kuriyama K, Nakamura T, Seto Y, Kato M, Hatanaka J, Tanaka T, Miyoshi H, Yamada S (2010b) Novel solid self-emulsifying drug delivery system of coenzyme Q10 with improved photochemical and pharmacokinetic behaviors. Eur J Pharm Sci 46:492-499

Onoue S, Aoki Y, Kawabata Y, Matsui T, Yamamoto K, Sato H, Yamauchi Y, Yamada S (2011a) Development of inhalable nanocrystalline solid dispersion of tranilast for airway inflammatory diseases. J Pharm Sci 100:622-633

Onoue S, Kuriyama K, Uchida A, Mizumoto T, Yamada S (2011b) Inhalable sustained-release formulation of glucagon: in vitro amyloidogenic and inhalation properties, and in vivo absorption and bioactivity. Pharm Res 28:1157-1166

Onoue S, Sato H, Ogawa K, Kojo Y, Aoki Y, Kawabata Y, Wada K, Mizumoto T, Yamada S (2012a) Inhalable dry-emulsion formulation of cyclosporine A with improved anti-inflammatory effects in experimental asthma/COPD-model rats. Eur J Pharm Biopharm 80:54-60

Onoue S, Matsui T, Kuriyama K, Ogawa K, Kojo Y, Mizumoto T, Karaki S, Kuwahara A, Yamada S (2012b) Inhalable sustainedrelease formulation of long-acting vasoactive intestinal peptide derivative alleviates acute airway inflammation. Peptides 35:182-189

Onoue S, Nakamura T, Uchida A, Ogawa K, Yuminoki K, Hashimoto N, Hiza A, Tsukaguchi Y, Asakawa T, Kan T, Yamada S (2013a) Physicochemical and biopharmaceutical characterization of amorphous solid dispersion of nobiletin, a citrus polymethoxylated flavone, with improved hepatoprotective effects. Eur J Pharm Sci 49:453-460

Onoue S, Kojo Y, Suzuki H, Yuminoki K, Kou K, Kawabata Y, Yamauchi Y, Hashimoto N, Yamada S (2013b) Development of novel solid dispersion of tranilast using amphiphilic block copolymer for improved oral bioavailability. Int J Pharm 452:220-226

Onoue S, Yamada S, Chan HK (2014) Nanodrugs: pharmacokinetics and safety. Int J Nanomed 20:1025-1037

Pandey R, Ahmad Z, Sharma S, Khuller GK (2005) Nano-encapsulation of azole antifungals: potential applications to improve oral drug delivery. Int J Pharm 301:268-276

Pathak P, Nagarsenker M (2009) Formulation and evaluation of lidocaine lipid nanosystems for dermal delivery. AAPS PharmSciTech 10:985-992

Pepic' I, Jalsenjak N, Jalsenjak I (2004) Micellar solutions of triblock copolymer surfactants with pilocarpine. Int J Pharm 272:57-64

Petros RA, DeSimone JM (2010) Strategies in the design of nanoparticles for therapeutic applications. Nat Rev Drug Discov 9:615-627

Piao H, Kamiya N, Hirata A, Fujii T, Goto M (2008) A novel solidin-oil nanosuspension for transdermal delivery of diclofenac sodium. Pharm Res 25:896-901

Prajapati RN, Tekade RK, Gupta U, Gajbhiye V, Jain NK (2009) Dendimer-mediated solubilization, formulation development and in vitro-in vivo assessment of piroxicam. Mol Pharm 6:940-950

Reddy LH, Murthy RS (2004) Pharmacokinetics and biodistribution studies of Doxorubicin loaded poly(butyl cyanoacrylate) nanoparticles synthesized by two different techniques. Biomed Pap Med Fac Univ Palacky Olomouc Czech Repub 148:161-166

Reddy LH, Sharma RK, Chuttani K, Mishra AK, Murthy RR (2004) Etoposide-incorporated tripalmitin nanoparticles with different surface charge: formulation, characterization, radiolabeling, and biodistribution studies. AAPS J 6:e23

Roger E, Lagarce F, Garcion E, Benoit JP (2010) Biopharmaceutical parameters to consider in order to alter the fate of nanocarriers after oral delivery. Nanomedicine 5:287-306

Salah EDTA, Bakr MM, Kamel HM, Abdel KM (2010) Magnetite nanoparticles as a single dose treatment for iron deficiency anemia. Hematol Am Soc Hematol Educ Program 2010:338-347

Sharma A, Sharma S, Khuller GK (2004) Lectin-functionalized poly(lactide-co-glycolide) nanoparticles as oral/aerosolized antitubercular drug carriers for treatment of tuberculosis. J Antimicrob Chemother 54:761-766

Shegokar R, Müller RH (2010) Nanocrystals: industrially feasible multifunctional formulation technology for poorly soluble actives. Int J Pharm 399:129-139

Strickley RG (2004) Solubilizing excipients in oral and injectable formulations. Pharm Res 21:201-230

Sylvestre JP, Tang MC, Furtos A, Leclair G, Meunier M, Leroux JC (2011) Nanonization of megestrol acetate by laser fragmentation in aqueous milieu. J Control Release 143:273-280 
Taylor DD, Gercel-Taylor C (2008) MicroRNA signatures of tumorderived exosomes as diagnostic biomarkers of ovarian cancer. Gynecol Oncol 110:13-21

Teshima M, Fumoto S, Nishida K, Nakamura J, Ohyama K, Nakamura T, Ichikawa N, Nakashima M, Sasaki H (2006) Prolonged blood concentration of prednisolone after intravenous injection of liposomal palmitoyl prednisolone. J Control Release 112:320-328

TGA (2016) Regulation of nanomedicines by the therapeutic goods administration

Thomas N, Holm R, Müllertz A, Rades T (2012) In vitro and in vivo performance of novel supersaturated self-nanoemulsifying drug delivery systems (super-SNEDDS). J Control Release 160:25-32

Thomas N, Holm R, Garmer M, Karlsson JJ, Müllertz A, Rades T (2013) Supersaturated self-nanoemulsifying drug delivery systems (Super-SNEDDS) enhance the bioavailability of the poorly water-soluble drug simvastatin in dogs. AAPS J 15:219-227

Tomii Y (2002) Lipid formulation as a drug carrier for drug delivery. Curr Pharm Des 8:467-474

Ur Rehman SS, Lim K, Wang-Gillam A (2016) Nanoliposomal irinotecan plus fluorouracil and folinic acid: a new treatment option in metastatic pancreatic cancer. Exp Rev Anticancer Ther 16:485-492

Wang-Gillam A, Li C-P, Bodoky G, Dean A, Shan Y-S, Jameson G, Macarulla T, Lee KH, Cunningham D, Blanc JF et al (2016)
Nanoliposomal irinotecan with fluorouracil and folinic acid in metastatic pancreatic cancer after previous gemcitabine-based therapy (NAPOLI-1): a global, randomised, open-label, phase 3 trial. Lancet 387:545-557

Watanabe M, Kawano K, Yokoyama M, Opanasopit P, Okano T, Maitani Y (2006) Preparation of camptothecin-loaded polymeric micelles and evaluation of their incorporation and circulation stability. Int J Pharm 308:183-189

Wu CY, Benet LZ (2005) Predicting drug disposition via application of BCS: transport/absorption/elimination interplay and development of a biopharmaceutics drug disposition classification system. Pharm Res 22:11-23

Xia D, Cui F, Piao H, Cun D, Piao H, Jiang Y, Ouyang M, Quan P (2010) Effect of crystal size on the in vitro dissolution and oral absorption of nitrendipine in rats. Pharm Res 27:1965-1976

Zhang N, Ping Q, Huang G, Xu W, Cheng Y, Han X (2006) Lectinmodified solid lipid nanoparticles as carriers for oral administration of insulin. Int J Pharm 327:153-159

Zhang L, Gu FX, Chan JM, Wang AZ, Langer RS, Farokhzad OC (2008) Nanoparticles in medicine: therapeutic applications and developments. Clin Pharmacol Ther 83:761-769

Zhang J, He C, Tang C, Yin C (2013) Ternary polymeric nanoparticles for oral siRNA delivery. Pharm Res 30:1228-1239 